\title{
Assessment of Genetic Variability, Heritability and Genetic Advance for Biometrical Traits in Fenugreek
}

\author{
Shyam Singh ${ }^{1}$, I.B. Maurya ${ }^{1}$, Bhuri Singh ${ }^{2}$, A. Kavita ${ }^{1}$, Rahul Chopra $^{3}$
}

10.18805/ag.R-2302

\begin{abstract}
Background: Fenugreek is a seed spice crop grown in arid and semi-arid areas of the world. The predominant growing areas are lacking with high yielding varieties and adopting poor crop husbandry. Therefore, the present study was focused on assessing the genetic variability among the diverse genotypes for their biometrical traits.

Methods: Thirty genotypes of fenugreek were sown in randomized block design with three replications during rabi season $2019-20$. Result: Presence of wide spectrum of variability among the genotypes for all the biometrical traits under study was evident. High GCV and PCV $(>20)$, heritability in broad sense $(>60)$ coupled with high genetic advance as percentage of mean $(>20 \%)$ was observed for proline content in leaves (mg/g) at 60 days after sowing (DAS) and physiological maturity, seed yield per plant, number of branches per plant, number of pods per plant, crude protein content and test weight suggesting that these characters are genetically governed by additive gene action and can be improved through selection.
\end{abstract}

Key words: Environments, Fenugreek, Genetic advance, Heritability, Variability.

\section{INTRODUCTION}

Fenugreek (Trigonella foenum-graecum L.) is a selfpollinated crop belonging to family Leguminosae with the number of chromosomes $2 n=2 x=16$ (Frayer, 1930). It is grown both for seed spice as well as leafy vegetable purpose. Its seeds have carminative property and its containing protein $(25.50 \%)$, fat $(7.90 \%)$, mucilaginous matter $(20.00 \%)$ and saponins (4.80\%) (Rao and Sharma, 1987). In India, it is mainly cultivated in Rajasthan, Gujarat, Tamil Nadu, Andhra Pradesh, Uttar Pradesh, Himachal Pradesh and Haryana. The crop was grown over an area of $1,81,000$ hectares with a production of $2,40,000$ metric tonnes (Anonymous, 2018). In Rajasthan, it occupies a prime position among the seed spices. More than 80 per cent of area and production of fenugreek in the country is contributed by Rajasthan state but the average productivity is very less. Its means there is no availability of suitable high yielding verities of fenugreek in this area. Therefore, it is an urgent need to identify new fenugreek genotypes with high genetic yield potential to achieve effective breeding programme. Genetic variability in fenugreek is still highly needed. Moreover, relative values of GCV and PCV give a reliable idea of the extent of variability in the population. It is also important to determine the amount of heritable variation by the estimate of heritability (Hanson, 1956). Therefore; this study was carried out to identify the potential fenugreek genotype with a distinct genetic variability to improve the fenugreek genotypes.

\section{MATERIALS AND METHODS}

The present study was conducted at Vegetable Farm, College of Horticulture and Forestry, Jhalawar. The experimental materials consisting of thirty genotypes of
1Department of Vegetable Science, College of Horticulture and Forestry, Jhalawar-326 023, Rajasthan, India.

${ }^{2}$ Department of Basic Science, College of Horticulture and Forestry, Jhalawar-326 023, Rajasthan, India.

${ }^{3}$ Department of Natural Resources Management, College of Horticulture and Forestry, Jhalawar-326 023, Rajasthan, India.

Corresponding Author: Bhuri Singh, Department of Basic Science, College of Horticulture and Forestry, Jhalawar-326 023, Rajasthan, India. Email: bhurisingh.gpb@gmail.com

How to cite this article: Singh, S., Maurya, I.B., Singh, B., Kavita, A. and Chopra, R. (2022). Assessment of Genetic Variability, Heritability and Genetic Advance for Biometrical Traits in Fenugreek. Agricultural Reviews. DOI: 10.18805/ag.R-2302.

Submitted: 11-06-2021 Accepted: 08-12-2021 Online: 17-01-2022

fenugreek are given in Table 1. The experiments were laid out in randomized block design with three replications during Rabi season 2019-20. Seeds of each genotype were sown in a two rows of $3 \mathrm{~m}$ row length in each replication with a spacing of $30 \times 10 \mathrm{~cm}$. All the recommended cultural practices were adopted uniformly in order to ensure a healthy crop stand. All the biometrical traits under study were recorded on five randomly plants in each genotype and each replication except days to 50 per cent flowering and days to maturity which were recorded on plot basis. Observations were recorded namely days to 50 per cent flowering, days to maturity, plant height at maturity $(\mathrm{cm})$, number of branches per plant, number of pods per plant, pod length $(\mathrm{cm})$, number of seeds per pods, test weight (g), seed yield per plant (g), total chlorophyll content in leaves $(\mathrm{mg} / \mathrm{g})$ at 60 days after sowing (DAS) and physiological maturity, proline content in leaves at 60 days after sowing (DAS) and physiological 
maturity and crude protein content (\%). The mean values were subjected to statistical analysis to work out ANOVA for all the biometrical traits, as suggested by Goulden (1959). The phenotypic and genotypic coefficient of variation was calculated as per the procedure given by Burton (1952). Heritability in broad sense was estimated based on the formula proposed by Lush (1940). Furthermore, genetic advance as per cent of mean was computed adopting the method given by Johnson et al. (1955).

\section{RESULTS AND DISCUSSION}

Analysis of variance was conducted to eliminate the variation due to causes other than genotypes from total variation. The ANOVA revealed highly significant variation among the genotypes $(p<0.01)$ for all the biometrical traits under study (Table 2). This suggests that the material had adequate genetic variability and response to selection may be accepted in the breeding programme for seed yield and its attributing traits. These results are in agreement with the findings of Ahari et al. (2009), Dashora et al. (2011), Verma and Ali (2012), Yadav et al. (2013), Kole and Saha (2014),

Table 1: List of thirty genotypes of fenugreek used in the study.

\begin{tabular}{|c|c|}
\hline S. no & Genotype \\
\hline 1 & RMt-305 \\
\hline 2 & GM-1 \\
\hline 3 & MP local-1 \\
\hline 4 & MP local-2 \\
\hline 5 & Jaipur local \\
\hline 6 & Karnataka local \\
\hline 7 & Chittorgarh local \\
\hline 8 & Jhalawar local \\
\hline 9 & Nagour local-2 \\
\hline 10 & RMt-303 \\
\hline 11 & RMt-143 \\
\hline 12 & Rajendra Kranti \\
\hline 13 & Hisar Suvarna \\
\hline 14 & AFG-1 \\
\hline 15 & Pant Ragni \\
\hline 16 & Jhunjhunu local \\
\hline 17 & Azad Methi \\
\hline 18 & Nagour local-1 \\
\hline 19 & Hisar Mukta \\
\hline 20 & $\mathrm{CO}-2$ \\
\hline 21 & Hisar Sonali \\
\hline 22 & RMt-351 \\
\hline 23 & GM-2 \\
\hline 24 & AFG-3 \\
\hline 25 & RMt-1 \\
\hline 26 & AFG-2 \\
\hline 27 & Lam selection \\
\hline 28 & Sikar local \\
\hline 29 & AFG-4 \\
\hline 30 & Hisar Madhavi \\
\hline
\end{tabular}

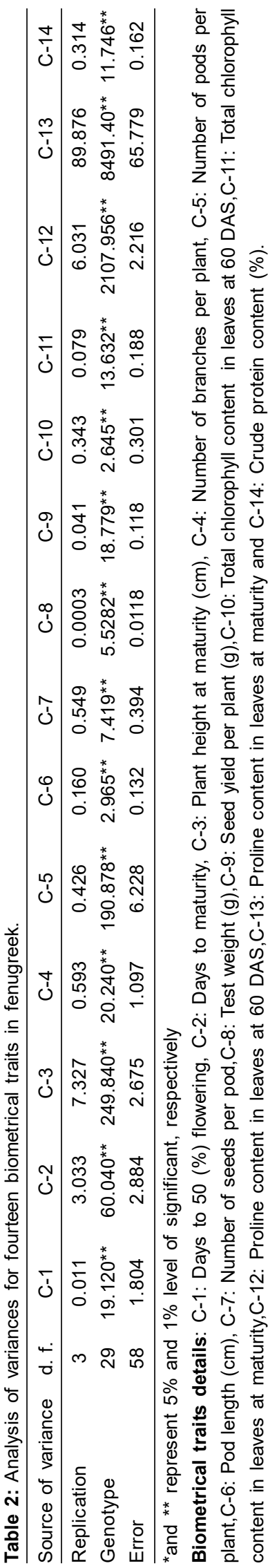




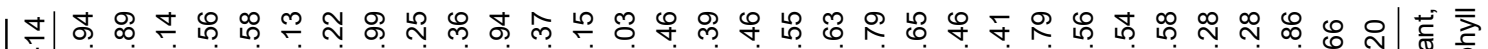

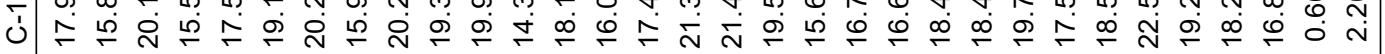

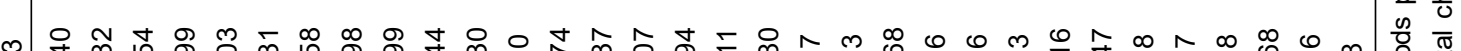

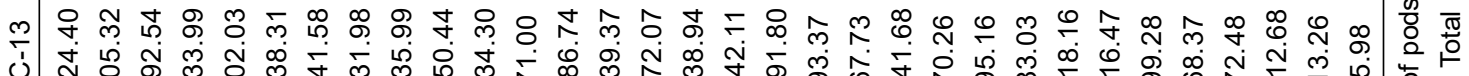

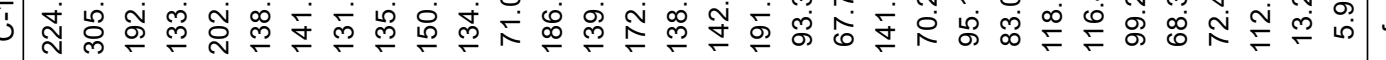

닌 ப́) 두일

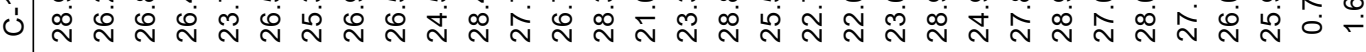

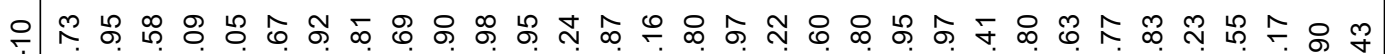
u

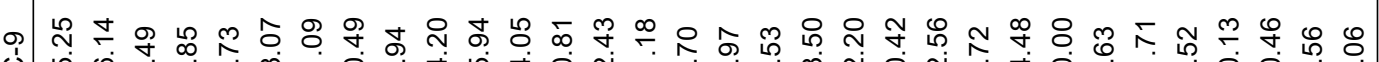
U

$\infty$ \& $\infty$

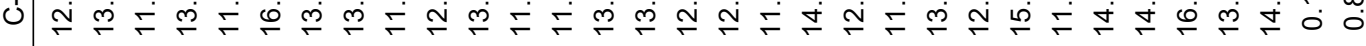

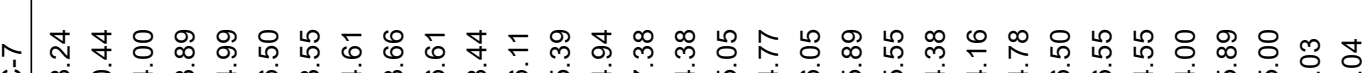

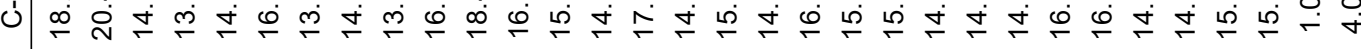

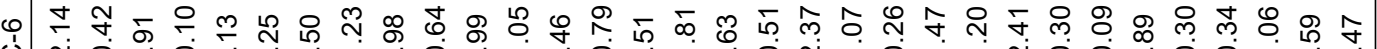

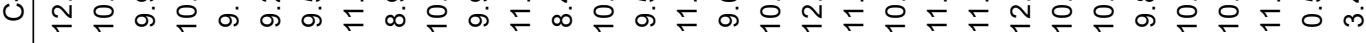

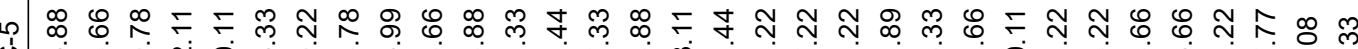
৩ 占舟 守

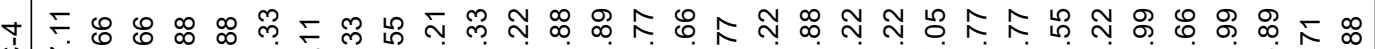

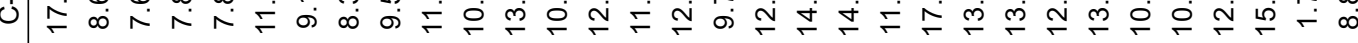

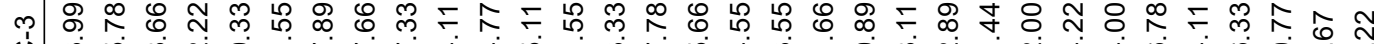
ט ๙

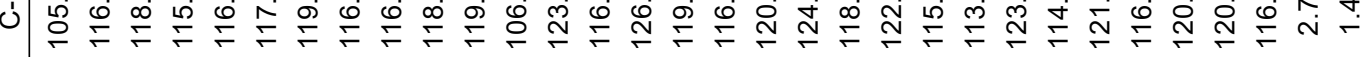

பं

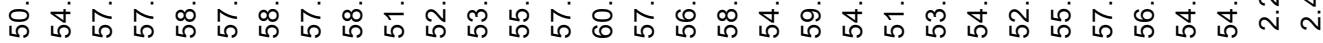


Sharma et al. (2015), Meena et al. (2017) and Singh and Naula (2017).

Further, the data obtained from the mean performance of the biometrical traits were presented in Table 3 and 4 . These data had sufficient variability among the genotypes. The results revealed that the traits such as days to 50 per cent flowering ranged from 50.33 days (RMt-305) to 60.33 days (Pant Ragini) with the mean value of 55.62 days, days to maturity varied from 105.33 days (RMt-305) to 126.33 days (Pant Ragini) with the mean value of 117.83 days, plant height at maturity was observed in minimum in RMt-305 $(53.99 \mathrm{~cm})$ and maximum in Hisar Sonali $(88.11 \mathrm{~cm})$ with the mean value of $73.57 \mathrm{~cm}$ number of branches per plant varied from 7.66 (MP local-1) to 17.11 (RMt-305) with the mean value of 11.79 minimum number of pods per plant was observed in Sikar local (45.66), while it was maximum in RMt-305 (765.88) with the mean value of 57.61 ,pod length ranged from $8.46 \mathrm{~cm}$ (Hisar Suvarna) to $12.41 \mathrm{~cm}$ (AFG-3) with the mean value of $10.46 \mathrm{~cm}$ number of seeds per pod ranged from 13.55 (Chittorghar local) to 20.44 (GM-1) with the mean value of 15.54 test weight ranged from $11.07 \mathrm{~g}$ (Hisar Sonali) to $16.62 \mathrm{~g}$ ' (Sikar local) with the mean value of $13.09 \mathrm{~g}$, mean seed yield per plant was recorded lowest in Sikar local $(7.52 \mathrm{~g})$, while highest in GM-1 (16.14 g) with the mean value of $11.21 \mathrm{~g}$, total chlorophyll content in leaves at 60 DAS ranged from $33.80 \mathrm{mg} / \mathrm{g}$ (AFG-3) to $39.95 \mathrm{mg} / \mathrm{g}$ (Rajendra Kranti) with the mean value of $38.38 \mathrm{mg} / \mathrm{g}$, and physiological maturity ranged from $21.06 \mathrm{mg} / \mathrm{g}$ (Pant Ragni) to $28.98 \mathrm{mg} / \mathrm{g}$ (RMt-305) with the mean value of $26.18 \mathrm{mg} / \mathrm{g}$, proline content in leaves at 60 DAS ranged from $30.65 \mathrm{mg} /$ $100 \mathrm{~g}$ (AFG-4) to $151.45 \mathrm{mg} / 100 \mathrm{~g}$ (GM-1) with the mean value of $66.96 \mathrm{mg} / 100 \mathrm{~g}$ and physiological maturity ranged from $67.73 \mathrm{mg} / 100 \mathrm{~g}(\mathrm{CO}-2)$ to $305.32 \mathrm{mg} / 100 \mathrm{~g}(\mathrm{GM}-1)$ with the mean value of $135.72 \mathrm{mg} / 100 \mathrm{~g}$ and crude protein content ranged from 14.37 per cent (Rajendra Kranti) to 22.58 per cent (Lam selection) with the mean value of 18.31 per cent.

In the present study the magnitude of phenotypic coefficient of variation (PCV) were found higher than the corresponding genotypic coefficient of variation (GCV) for all the biometrical traits studied (Table 4). It means the apparent variation is not only due to genotypes but also due to environment. Thus, the selection could be made on the basis of phenotypic performance offering scope for crop improvement. The estimation of phenotypic coefficients of variation (PCV) and genotypic coefficients of variation (GCV) were highest $(>20 \%)$ for proline content in leaves at 60 DAS (39.63 and 39.57) and physiological maturity (39.50 and $39.05)$, seed yield per plant (22.47 and 22.26) and number of branches per plant (23.19 and 21.43). Thus, selection might be more effective for these biometrical traits because the response to selection is directly proportional to the variability present in the experimental material. Similar findings were also reported by Pathak et al. (2014), Narolia et al. (2017) and Panwar et al. (2017).

The magnitude of broad sense heritability ranged from 72.18 (total chlorophyll content in leaves at 60 DAS) to 99.69

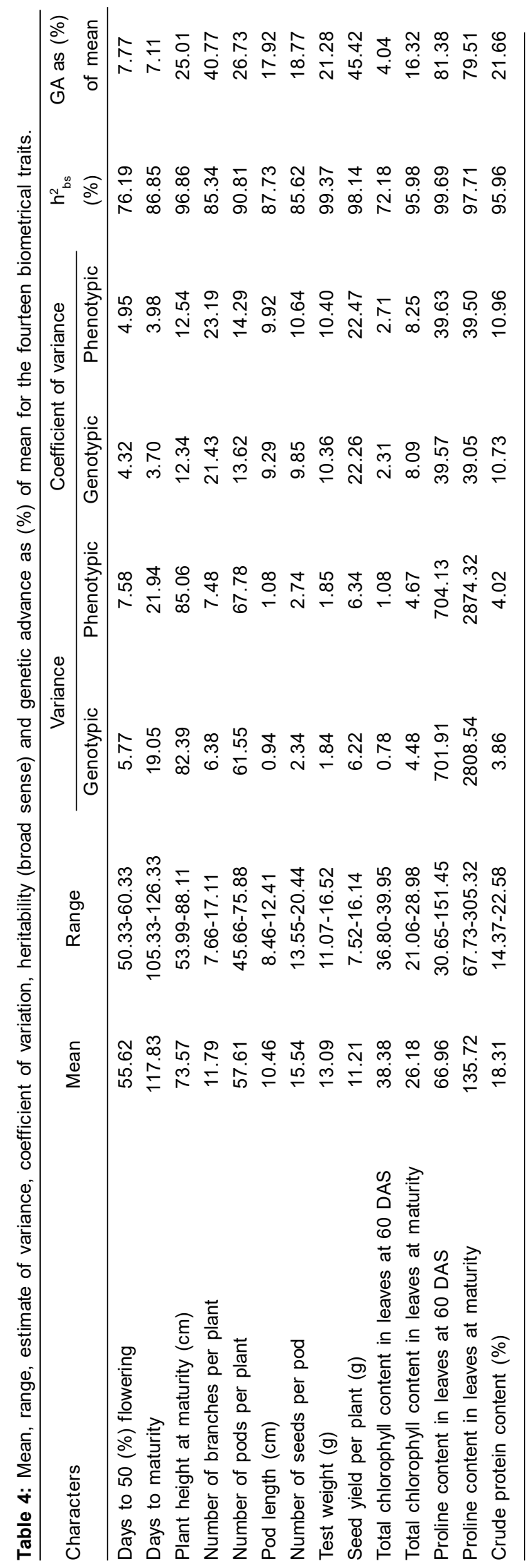


(proline content in leaves at 60 DAS). All the studied traits showed high heritability (Table 4). Similar findings were also reported by Singh and Naula (2017), Singh et al. (2019) and Verma et al. (2016).

Johnson et al. (1955) has pointed out that heritability estimate along with genetic advance were more useful than heritability estimates alone in predicting the response to selection. Therefore, genetic advance as percentage of mean was calculated in order to determine the relative merits of different traits that can be further utilized in the selection programme. The expected genetic advance as percentage of mean $(>20 \%)$ recorded maximum with proline content in leaves at 60 DAS (81.38) and physiological maturity (64.38), seed yield per plant (45.42), number of branches per plant (40.77), number of seeds per pod (26.73), plant height at maturity (25.01), crude protein content (21.66) and test weight (21.28). These results are in agreement with Pathak et al. (2014), Mamatha et al. (2017) and Naroliya et al. (2017).

High heritability $(>60 \%)$ coupled with high genetic advance as a percentage of mean ( $>20 \%$ ) was observed for proline content in leaves at 60 DAS and physiological maturity, seed yield per plant, number of branches per plant, number of pods per plant, crude protein content and test weight indicating the presence of additive gene action.

The rest of biometrical traits, days to 50 per cent flowering, days to maturity, pod length, total chlorophyll content in leaves at 60DAS and physiological maturity and plant height at maturity showed high heritability associated with low genetic advance as percent of mean due to less GCV value. The reported results are in agreement with the findings of Kumari et al. (2015).

\section{CONCLUSION}

Present study of variation indicated substantial variability among the genotypes as well as the biometrical traits. The traits viz., Proline content in leaves at 60 DAS and physiological maturity, seed yield per plant, number of branches per plant, number of pods per plant, crude protein content and test weight showed high value for GCV, heritability in broad sense and expected genetic advance as percentage of mean. Thus, these traits should be considered during selection. Further, the promising genotypes which showed high values for the abovementioned important traits were RMt-143, RMt-305, GM-1, AFG-3, RMt-303 and Rajendra Kranti.

\section{REFERENCES}

Ahari, D.S., Kashi, A.K., Hassandokht, M.R., Amri, A., Alizadeh, K. (2009). Assessment of drought tolerance in Iranian fenugreek (Trigonella foenum-graecum L.). Journal of Food, Agriculture and Environment. 7(3 and 4): 414-419.

Anonymous, (2018). Agricultural Statistics at a Glance. Ministry of Agriculture and Farmers Welfare,New Delhi. pp 186.

Burton, G.W. (1952). Quantitative inheritance in grasses. Proceeding of $6^{\text {th }}$ International Grassland Congress. 1: 277-283.
Dashora, A., Maloo, S.R. and Dashora, L.K. (2011). Variability, correlation and path coefficient analysis in fenugreek (Trigonella foenum-graceum L.) under water limited conditions. Journal of Spices and Aromatic crops. 20(1): 38-42.

Frayer, J.R. (1930). Chromosome atlas of flowering plants. George Allen and Urwin, London. pp. 519.

Goulden, O.C. (1959). Methods of Statistical Analysis (2 ${ }^{\text {nd }}$ Edition), Willey and Sons, Inc., New York.

Hanson, C.H., Robinson, H.P., Comstock, R.E. (1956). Biometrical studies of yield in segregating populations of Korean Lespedeza. Agronomy Journal. 48(5): 268-272.

Johnson, H.W., Robinson, H.F., Comstock, R.E. (1955). Estimate of genetic and environmental variability in soybean. Agronomy Journal. 47(7): 314-318.

Kole, P.C. and Saha, A. (2013). Studies on variability and heritability for different quantitative characters in fenugreek (Trigonella foenum-graceum L.). Journal of Plant Breeding and Crop Science. 5(11): 224-228.

Kumari, J., Kulkarni, G.U., Sharma, L.K. (2015). Studies on genetic variability, correlation and path analysis in fenugreek (Trigonella foenum-graceum L.). Frontiers in Crop Improvement. 3(1): 46-48.

Lush, J.L. (1940). Intro-site correlation and regression of off spring corn as a method of estimating heritability of characters. Proceedings American Society of Animal Production. 33(4): 293-301.

Mamatha, N.C., Tehlan, S.K., Srikanth, M., Ravikumar, T., Batra, V.K., Reddy, P.K., Kumar, M. (2017). Variability studies for yield and its attributing traits in fenugreek (Trigonella foenum-graecum L.). International Journal of Pure Applied Bioscience. 5(3): 1075-1079.

Meena, R.P., Singh, D., Meena, B.L., Meena, S.K., Kumari, R. (2017). Evaluation of fenugreek (Trigonella foenum-graecum L.) genotypes under normal and limited moisture conditions. Journal of Plant Development Sciences. 9(4): 283-295.

Narolia, S.L., Meena, M.L., Atal, M.K. and Verma, N. (2017). Genetic variability, heritability and genetic advance in fenugreek (Trigonella foenum-graecum L.) genotypes. International Journal of Pure Applied Bioscience. 5(6): 452-458.

Panwar, A., Sharma, Y.K., Meena, R.S., Solanki, R.K., Aishwath, O.P., Singh, R. Choudhary, S. (2017). Genetic variability, association studies and genetic divergence in Indian fenugreek (Trigonella foenum-graecum L.). Legume Research. 41(6): 816-821.

Pathak, A.R., Patel, A.I., Joshi, H.K., Patel, D.A. (2014). Genetic variability, correlation and path coefficient analysis in fenugreek (Trigonella foenum-graecum L.). Trends in Biosciences. 7(4): 234-237.

Rao, P.U. and Sharma, R.K. (1987). An evaluation of protein quality of fenugreek seed (Trigonella foenum-graecum L.) and their supplementary effects. Food Chemistry. 24(1):1-9.

Sharma, N., Shekhawat, A.S., Malav, S., Meena, C.P. (2015). Genetic variability and stress susceptibility index under limited moisture condition in fenugreek (Trigonella foenumgraecum L.). Green Farming. 6(1): 37-40.

Singh, A. and Naula, R. (2017). Variability parameters for growth and yield characters in fenugreek. International Journal of Agriculture Sciences. 9(14): 4077-4080. 
Singh, A.K., Singh, D.R., Singh, A., Maurya, J.K., Pandey, V.P., Sri, O.M. (2019). Studies on character association and path analysis of yield with important yield contributing traits in fenugreek (Trigonella foenum-graecum L.). Journal of Pharmacognosy and Phytochemistry. 8(3): 4616-4619.

Varma, P., Solanki, R.K., Dhasora, A., Kakani, R.K. (2016). Genetic variability in fenugreek (Trigonella foenum-graecum L.) as expressed under South Eastern region of Rajasthan state. International Journal of Seed Spices. 6(1): 93-95.
Verma, P. and Ali, M. (2012). Genetic variability in fenugreek (Trigonella foenum-graecum L.) assessed in South Eastern Rajasthan. International Journal of Seed Spices. 2(1): 56-58.

Yadav, Y., Yadava, P., Pandey, V.P., Kumar, A. (2013). Genetic variability, correlation and path coefficient analysis studies in fenugreek (Trigonella foenum-graceum L.). The Asian Journal of Horticulture. 8(2): 456-459. 